\title{
Research on Influencing Factors of Executive Compensation in China's Monopoly Industries
}

\author{
Yun Dai \\ Business School, Nantong University, Jiangsu, China \\ Email: d yun@126.com
}

Received 11 May 2014; revised 15 June 2014; accepted 5 July 2014

Copyright (C) 2014 by author and Scientific Research Publishing Inc.

This work is licensed under the Creative Commons Attribution International License (CC BY).

http://creativecommons.org/licenses/by/4.0/

(c) (i) Open Access

\begin{abstract}
The annual salary income of the executives in the state-owned monopoly industry has become the focus of the society recently. With the improvement of enterprise efficiency, executives deserve to get high pay. However, it's should be noted that because of the state-owned monopolies' special status, business performance relies heavily on administrative monopoly power, but not actually the efforts of leaders. In this case, the income distribution mechanism is distortion, which has caused great dissatisfaction. This paper aims to study the main affecting factors of the executive compensation of state monopolies, with 1280 firm-year observations of 183 monopoly companies. We find that 1) Executive compensation is positively correlated to firm performance, firm size, CEO duality; 2) Executive compensation is negatively correlated to state share proportion and independent director proportion; 3) Company location, industry both have significant influence on executive compensation.
\end{abstract}

\section{Keywords}

Monopoly, Executive Compensation, Factors, Firm Performance, CEO Duality

\section{Introduction}

China has achieved impressive economic growth since market reforms were first introduced some 30 years ago. Accompanied by the economic modernization of China is the corporatization of State Owned Enterprises (SOEs), among them are monopoly enterprises. The China monopoly enterprises mainly concentrate in the industries that concern the national economy, such as transportation, electric power, telecommunications, energy. These enterprises do not participate in the market competition, but have an absolute advantage in resources, policies, and obtain huge profits by virtue of its monopoly position. The astronomical salary of executives has 
caused great dissatisfy action and is not conducive to the establishment of the harmonious society. Finding out the factors affecting executive compensation is of great importance to establish effective and equitable compensation mechanism.

Examining the association between relative factors and executive pay is not new. However, relatively few studies focus on the monopoly industries. The earliest executive compensation researchers are Taussings and Baker [1], who found a weak correlation between executive compensation and corporate performance. Tosi and Gomez-Mejia [2] found that the explanatory power of firm scale on executive pay is $40 \%$, while the explanation of firm performance is only $5 \%$. However, some researchers also proved the positive correlation between executive compensation and corporate performance. Lewellen and Huntsman [3] found that the accounting profits and sales revenue both affected executive compensation. Schmidt and Coughlan [4] proved that changes in top management cash compensation were positively related to the changing market returns. Jensen and Murphy [5] found that for every $\$ 1000$ increase in shareholder wealth, executive pay increased by 2.19 cents. Hall and Liebman [6] pointed out that the sensitivity of the executive compensation on the performance is high and increasing. Sapp [7] found that the relationship between corporate governance factors and executive compensation was very significant. Conyon and He [8] took Chinese listing companies as sample, finding that corporation executive compensation was positively correlated with enterprise scale, enterprise performance and growth opportunities, while negatively with the risk of the company. Kevin [9] concluded that executive compensation was positively related to company performance measured by the rate of return on net assets, and the firm size is the most significant factor affecting the level of executive compensation with 280 companies listed at the New York Stock Exchange in 2006-2009.

The subject of our study is the compensation of CEOs in China's monopoly enterprises. We collect the crosssectional data from 2004-2011 released by monopoly listed companies. In addition, regression statistical model is adopted to analyze the influencing factors of executive compensation. The analysis results can provide scientific evidences on the relationship between the executive compensation and its affecting factors, presenting a relatively objective status of executive compensation of China's monopoly enterprises, which will be a great help to executive compensation designs.

The rest of this article is structured as follows: Section 2 discusses the institutional background, and reviews the literature. Section 3 develops the hypotheses. Methodologies are described in Section 4, and empirical results are presented in Section 5. Section 6 concludes this study.

\section{Institutional Background and Literature Review}

\subsection{A Brief History of the Chinese Compensation System}

China began its economic reform in 1978, since then the goal of Chinese economic transition from planned to market-based system was gradually made. Accompanying China's economic transition is the compensation reform, especially there form for executives in Chinese state-owned enterprises (SOEs). Prior to the reform, China implemented a simple, rigid, and universal compensation system in which SOEs were not allowed to keep any profits. As a result, executive's compensation, determined centrally, was not based on performance [10]; rather, other factors, such as job title, seniority, size of the firm, industry, and region, mainly determined how much executives were compensated [11]. In mid-1980s, a major compensation reform was implemented so that SOEs were allowed to retain a portion of the profits to reward their employees as well as their executives. From 1984 to 1993, executive's compensation in SOEs was link to that of the firm performance. In 1994, a yearly compensation system consisting of the base salary and the incentive-pay for SOE executives was implemented throughout the country, which was then considered successful and became the dominant compensation practice for SOE executives, especially in large firms [11]. Since the enactment of "Temporary regulations of performance evaluation, on the central state enterprise's executives" in 2003, performance-related pay was rapidly increased, making executive compensation a social focus. In 2009, the government again issued guidance on the executive's compensation in central state enterprises, in order to limit excessive compensation of executives.

\subsection{Literature Review}

\subsubsection{Agency Theory}

The detachment of operating rights and ownership incurs so-called agency problem. Due to the inconsistency of 
owners and operators, operators in pursuit of their own interests are likely to damage the interests of the shareholders. Compensation research based on agency theory is divided into two schools, one is the principal-agent theory, which is also known as information economics, and the other is positivism, which mainly researches on managers' pay-performance sensitivity.

The most basic way contact managers and shareholders is the performance of enterprises. Agency costs arise because of managerial self-interest behavior. In order to reduce agency cost, shareholders have to directly link executive compensation to enterprise performance. From this viewpoint, we think that the performance of the company is the basic factor to determine the level of executive compensation.

\subsubsection{Human Capital Theory}

Human capital theory discusses the salary decision mechanism from the viewpoint of management of their own. Executives with a greater ability to bring more profits to the enterprises should get more pay.

Agrawal [12] found that executive pay level actually depended on the marginal productivity, which was determined primarily by the operator's human capital investment, including experience, tenure and education level. Human capital is a special property right because it can only exist in the executive's body, not be separated from the managers and exist alone. At the same time, as a decision maker, manager not only needs to have the advanced management idea and abundant professional knowledge, but also a keen insight and control of the situation. All of these have influence on the executive compensation.

\subsubsection{Managerial Power Approach}

Agency theory deems that designing the optimal compensation contract will bring about the biggest wealth for shareholders; while managerial power theory has a counter idea that managers can influence compensation contract design, for they have the ability to influence the decisions of the board. Bebchuk [13] put forward a new compensation theory based on managerial power: that is, the negotiation between the board on behalf of shareholders and managers is a very complex multi-agency relationship. It leads managers to use their power to influence the decisions of the board, thus making compensation deviate from the optimal contract, so the salary decision process will become a way for managers rent seeking. Due to the failure of corporate external governance mechanism, managers actually control the process of their remuneration decision, and this power usually depends on the form of the board and ownership structure.

\section{Theoretical Analysis and Research Hypotheses}

According to the former related research, combining the characteristics of executive compensation in China's state-owned monopoly enterprises and data collected, this paper mainly analyses the factors affecting executive pay from four aspects, including corporate characteristics, governance structure, executive characteristics and external factors.

\subsection{Corporate Characteristics}

\subsubsection{Industry}

The industry factor has two main effects on executive compensation: First, different industries with differences in profit model, profit level and risk, lead to different executive compensation. In general, the more intense of industry competition, the higher level of executive compensation. At the same time, fierce competition will improve the liquidity of the executives, so enterprises would improve the compensation in order to retain talent ones.

\subsubsection{Firm Size}

Mengistae and Xu [14], Firth, et al. [15] [16], Li, et al. [17], and Conyon and He [18] found that the compensation level increased with firm size, possibly because larger firms are more complex and hence require more management skills or because they have a larger resource base to attract top talent with higher salaries. In addition, the larger the enterprise scale, the more difficult to supervise the executive. In order to reduce agency cost, business owners will adopt the above-market compensation to motivate executives to work hard.

\subsubsection{Firm Performance}

Agency theory suggests firms will link pay to performance to motivate managers [19]. As we know, there is 
asymmetric information flow between the managers and the owners. The company owners will base the executive's pay on the corporation's performance in order to reduce the agency costs. Thus, executive compensation should not be contact with the performance of enterprises, but also with the performance of stock markets. However, it is worth noting that cash compensation for executives dominates stock options in Chinese listed companies. Considering the limitations of information disclosure of stock options of executives, also following Firth et al. [15] and Kato and Long [11], we only consider the cash compensation for executives in the current study.

\subsubsection{Firm Location}

Enterprise location also has a greater impact on executive compensation. There exist great differences in different regions in terms of executive's compensation. Cities such as Beijing, Shanghai, Guangzhou are developed regions, and the central and western regions are relatively backward. Generally speaking, executive pay in developed areas is much higher than that in less developed areas. From the results showed below that the average executive compensation in developed areas (RMB539987.28) is almost twice as much as that in underdeveloped areas (RMB287220.10).

\subsection{Governance Structure}

\subsubsection{Independent Director Proportion}

The proportion of independent directors will be an important factor influencing executive salaries. According to Weisbach [20], independent directors have no direct interest relationship to executives, so they can be more objective and impartial when evaluating executive, from the viewpoint of the share holders' interests. In addition, the independent directors are the elite from various sectors, and they are willing to take the initiative to supervise the executive, in order to keep their reputation. However, other researches have different viewpoints. In order to remain with the company, independent directors generally will not challenge executive's pay, because CEO has the ability to nominate and replace independent directors. In addition, independent directors are usually served in many companies, and they have no enough time to involve in the company's daily operations. As a result, they do not quite understand corporation performance to make an objective evaluation on executive's contribution [21].

\subsubsection{Ownership Structure}

According to the management power theory, the more dispersed the ownership structure of the company, the easier the agent is to control the company. In this way, the agent (manager) will be in the dominant position in the process of compensation contract negotiation for a high pay. On the contrary, if the ownership structure of enterprises is more concentrated, the principal (owner) rather than agent can control the compensation contract terms, making the executive in the inferior position with a relatively lower pay. One of the major characteristics of Chinese state-owned monopoly enterprises is the domination by controlling share holders. The shares owned by central government usually reach $50 \%$, even higher. This owner ship structure weakens the effectiveness of corporate governance. So we can speculate that the government will limit executive's authority on compensation self-making, to avoid excessive high pay.

\subsection{Executive Characteristics}

\subsubsection{Age and Experience}

As business manager, executives need a lot of management ability. According to human capital theory, executive compensation should be linked with knowledge and skills. With age growing, richer experience and gradually improving management skills, executive's salary level should also be improved. At the same time, rich social experience expands the executive’s social resources, making them more likely to work, also get higher pay.

\subsubsection{CEO Duality}

There is evidence that executive compensation levels are lower in firms with separate leadership positions [22] [23]. CEO duality not only damages the independence of the board of directors, but also makes the insider control problem more serious. CEO at the same time as the chairman of the board, has more power on compensation determination, leading to a high pay level. It is worth pointing out that, China Securities Regulatory Commission 
(CSRC) proposed the separation of duties as an important measure for the effectiveness of corporate governance.

\subsection{External Factors}

\subsubsection{Market Supply and Demand}

According to the theory of micro economics, market prices is determined by market supply and demand, what is also true in the labor market. If talent available is in short supply, enterprises have to raise the pay to attract them; on the contrary, if the labor oversupply, enterprises can introduce talents with low compensation, helping to reduce production costs.

\subsubsection{National Policies and Laws}

Executive compensation will be affected by the national policies, laws and regulations. Especially for the stateowned monopoly enterprises, executive's behavior is subject to the relevant policies and regulations which support or restrain their high pay.

This paper studies influencing factors of executive compensation in China's monopoly industries. Based on the factors illustrated above and data quantifiable, our hypotheses are developed as follows:

Hypothesis 1: Executive compensation is positively correlated to firm performance.

Hypothesis 2: Executive compensation is positively correlated to firm size.

Hypothesis 3: Executive compensation is positively correlated to CEO duality.

Hypothesis 4: Executive compensation is negatively correlated to independent director proportion.

Hypothesis 5: Executive compensation is negatively correlated to state share proportion.

\section{Sample and Methodology}

\subsection{Sample and Data Sources}

The primary data we use in this article are obtained from the China Stock Market and Accounting Research (CSMAR) database. Since the enactment of "Temporary regulations of performance evaluation on the central state enterprise's executives” in 2003, we choose our sample period from 2004 to 2011. The corporation selection criteria we use are as follows: 1) Exclude those corporations which are labeled as ST and PT; 2) Consider those listed companies only with A shares but no B or H shares; 3) Exclude companies in the financial sector; 4) Exclude those corporations with incomplete disclosed financial data. The sample consists of 183 monopoly companies and 1280 firm-year observations.

In line with other studies, we definite monopoly industrial classification based on the "China Statistical Yearbook (2007)", taking into account the CSMAR industry classification. The final is determined as the following 14 monopoly industries: Petroleum and natural gas industry; Coal mining industry; Nonferrous metal mining industry; Electricity, steam, hot water production and supply industry; Tap water production and supply industry; Gas production and supply industry; Public facilities services; Petroleum processing and coking industry; Communication services; Railway transportation industry; Road transportation industry; Water transportation industry; Air transportation industry and auxiliary transportation industry.

\subsection{Variables Definitions}

\subsubsection{Dependent Variable: Executive Compensation (EC)}

This article only considers the top three executives remuneration packages which include the fixed remuneration (basic salary) and short-term compensation (variable pay). We use EC, which is measured by the average pay of top three executives, as our dependent variable.

\subsubsection{Independent Variables}

Following prior literature and considering the China-specific context, we examine our research questions by determining these independent variables, including firm performance, firm size, board independence, ownership structures, CEO duality.

The net asset return rate (ROE), reflecting the profitability of a corporation, is adopted to measure firm performance. Since the corporations with varying sizes will give out different remuneration packages, this paper 
uses the log of total assets (denoted SIZE) as an indicator of the firm size. The percentage of independent directors on the board (denoted IDR) is used as a proxy of board independence. In monopoly companies, the largest shareholder is usually the State, so we use the state share proportion (denoted FST) to reflect ownership structures. To measure the separation of duties, we include a dummy variable, DUAL, to indicate whether the chairman of the directors board is also the CEO of the company, which equals one if the same person assumes both positions, and zero otherwise. According to the location of the company, we divide the whole sample into two parts-developed areas and underdeveloped areas. 11 provinces and autonomous regions, including Beijing, Tianjin, Hebei, Liaoning, Shanghai, Jiangsu, Zhejiang, Fujian, Shandong, Guangdong and Hainan are classified as the developed areas. The synthetic variable AREA indicates whether the location is in underdeveloped areas ( 0 value) or developed areas ( 1 value).

\subsubsection{Control Variables}

We include a set of time dummies (denoted YEAR) to capture year effects and industry dummy variables (denoted IND) to capture industry variation. The industry classification is based on the "China Statistical Yearbook (2007)" categorization specified above.

\subsection{Model and Methods}

The model for evaluating the influencing factors of executive compensation is as follows:

$$
E C=\beta_{0}+\beta_{1} R O E+\beta_{2} S I Z E+\beta_{3} D U A L+\beta_{4} I D R+\beta_{5} F S T+\beta_{6} A R E A+\beta_{7} I N D+\beta_{8} Y E A R+\varepsilon
$$

First, simple descriptive statistics are applied on the collected data to calculate the maximum, minimum, average and standard deviation and to analyze the sample's characteristics and understand the variables' distribution. The regression analysis is conducted on the independent and dependent variables to confirm the regression model and proposed hypothesis, then illustrate the relationship between the independent variables and the dependent variables.

\section{Empirical Results}

\subsection{Descriptive Statistical Analysis}

Table 1 presents the descriptive statistics for the full sample, the subsample in developed areas, and that in underdeveloped areas, respectively; and the results show that the average executive compensation in developed regions (RMB539987.28) is much higher than that in underdeveloped regions (RMB287220.10). However, the difference between regions on other variables such as ROE, SIZE, IDR, FST is not obvious.

The variable EC is average pay of top three executives. ROE is net income divided by total equity. SIZE is computed using the natural logarithm of total assets. DUAL is a dummy variable with a value of one if the board chair also serves as the CEO, zero otherwise. IDR indicates the proportion of independent directors on the board. FST is the shareholding ratio of state-owned shares.

\subsection{Correlation Analysis}

The correlation matrix is reported in Table 2. Table 2 suggests that top executive compensation is positively related to firm performance, firm size, independent director proportion and areas, while is negatively related to the state share proportion. In addition, according to the statistical data, correlations among the independent variables are low (the maximum is 0.313 ) and so multicollinearity is not a major problem.

\subsection{Regression Analysis}

The results of the regression analysis for the model are shown in Table 3. As can be seen from Table 3, executive compensation is significantly positively linked with both firm performance and firm size, thus supporting Hypothesis 1 and 2. In addition, the coefficient of SIZE is obviously higher than coefficient of ROE, showing that in China's monopoly companies, the corporation's size is the key factor influencing the executive compensation. The independent variables AREA and DUAL are significant at the $1 \%$ and $10 \%$ level respectively, suggesting that the location of the company and CEO duality has positive impact on executive compensation, in 
Table 1. Descriptive statistics of the sample variables.

\begin{tabular}{ccccccc}
\hline Variable & & Number of samples & Min & Max & Mean & Std. deviation \\
\hline & EC & 1280 & 15333.33 & 3748066.80 & 395831.00 & 353219.03 \\
& ROE & 1280 & -0.346 & 0.590 & 0.055 & 0.067 \\
All samples & SIZE & 1280 & 19.24 & 28.28 & 22.42 & 1.501 \\
& DUAL & 1256 & 0 & 1 & 0.09 & 0.293 \\
& IDR & 1260 & 0.125 & 0.667 & 0.356 & 0.050 \\
& FST & 1275 & 0.000 & 0.863 & 0.328 & 0.264 \\
& EC & 550 & 56666.67 & 3748066.80 & 539987.28 & 434839.91 \\
& ROE & 550 & -0.163 & 0.241 & 0.059 & 0.055 \\
& SIZE & 550 & 19.70 & 28.28 & 22.965 & 1.680 \\
& DUAL & 532 & 0 & 1 & 0.080 & 0.273 \\
& IDR & 542 & 0.200 & 0.667 & 0.359 & 0.047 \\
& FST & 547 & 0.000 & 0.863 & 0.324 & 0.271 \\
& EC & 730 & 15333.33 & 2600633.20 & 287220.10 & 221368.08
\end{tabular}

Table 2. Correlation matrix of key variables.

\begin{tabular}{|c|c|c|c|c|c|c|c|}
\hline & EC & ROE & SIZE & DUAL & IDR & FST & AREA \\
\hline EC & 1 & & & & & & \\
\hline ROE & $0.200^{* *}$ & 1 & & & & & \\
\hline SIZE & $0.439^{* *}$ & $0.099^{* *}$ & 1 & & & & \\
\hline DUAL & -0.022 & -0.017 & $-0.190^{* *}$ & 1 & & & \\
\hline IDR & $0.068^{*}$ & 0.031 & $0.078^{* *}$ & 0.027 & 1 & & \\
\hline FST & $-0.134^{* *}$ & $0.138^{* *}$ & 0.042 & $-0.067^{*}$ & $-0.129^{* *}$ & 1 & \\
\hline AREA & $0.354^{* *}$ & 0.050 & $0.313^{* *}$ & -0.041 & 0.046 & -0.013 & 1 \\
\hline
\end{tabular}

*, ${ }^{* *}$ represent $5 \%$ and $1 \%$ significance level respectively (2-tailed).

Table 3. Multiple regression results of influencing factors of executive compensation.

\begin{tabular}{cccc}
\hline Variable & Coefficient & t Value & VIF \\
ROE & $0.145^{* * *}$ & 5.824 & 1.251 \\
SIZE & $0.306^{* * *}$ & 10.746 & 1.647 \\
DUAL & $0.041^{*}$ & 1.773 & 1.070 \\
IDR & -0.011 & -0.469 & 1.067 \\
FST & $-0.069^{* * *}$ & -2.659 & 1.351 \\
AREA & $0.246^{* * *}$ & 9.435 & 1.379 \\
& IND (Controlled) & & \\
& YEAR (Controlled) & & \\
& Adjusted R Square 0.389 & & \\
\end{tabular}

\footnotetext{
${ }^{*},{ }^{* *},{ }^{* * *}$ represent $10 \%, 5 \%$ and $1 \%$ significance level respectively.
} 
line with Hypothesis 3 and 6. Then, the coefficient on FST is significantly negative, while is insignificant on IDR, supporting Hypothesis 5, not Hypothesis 4. It appears that in China, high ratio of independent directors has efficiency problems in supervising executive high compensation.

\subsection{Robustness Tests}

Robustness tests are done using alternative proxies for firm performance, firm size, and ownership structure variables. We have found no qualitative change in the results. Variance inflation factors (VIF) are estimated; our empirical results are not biased due to potential multicollienarity. In short, we conclude that the empirical results presented in this study are robust.

\section{Conclusions and Future Research}

Based on the Agency Theory, Human Capital Theory as well as Managerial Power Approach, considering the characteristics of Chinese monopoly industries, the study gives a further analysis of the influencing factors of executive compensation in China's monopoly companies. Through the empirical research, this paper comes to the following conclusions:

1) Executive compensation is positively correlated to firm performance and firm size. Meanwhile, the quantitative analysis reveals that the influence of the scale does far outweigh the influence of performance, showing that the firm size is an important factor influencing the executive compensation in China's Monopoly companies. In addition, the positive relationship between executive pay and firm performance shows that at present in state monopolies, shareholders judge executive effort by corporate performance, and then decide how much the executives are paid. But the problem is, to what extent firm performance can reflect the degree of executives' effort? In other words, among enterprise performance, how much comes from managers' efforts, and how much comes from enterprise itself inherent conditions, then how much comes from the monopoly granted by government? From this viewpoint, a fairer and reasonable income distribution mechanism should be established in state monopolies.

2) Executive compensation is positively correlated to CEO duality, at the same time, negatively correlated to state share proportion and independent director proportion, although not significant to the latter. In a sense, CEO duality, low state share proportion and low independent director proportion, all represent higher managerial power. So we suggest that by introducing competition mechanisms and perfecting the corporate governance structure, we can inhibit the direct influence of the management power to salary and reduce the dominant management power pay.

3) Company location, industry both have significant influence on executive compensation. This conclusion further confirms the results present in former compensation literature.

Our study also indicates some future research avenues. First, Chinese listed firms still only have to report the mix of salary, bonus, and other remuneration. This relatively primitive compensation disclosure system prevents us from distinguishing between different components of executive compensation and makes it difficult to justify the appropriateness of Chinese executive compensation. In addition, the accounting and management literature using the US data has shown that equity incentives play an important role in executive compensation [24]. The CSRC now demands more detailed disclosure in executive compensation, and allows the usage of equity incentives in China. As such it provides opportunities for future research to further explore the role of equity incentives and other pay components in Chinese executive compensation.

\section{References}

[1] Taussig, F.W. and Baker, W.S. (1925) American Corporations and Their Executives: A Statistical Inquiry. Quarterly Journal of Economic, 40, 1-51.

[2] Tosi, H.L., Werner, S., Katz, J.P. and Gomez-Mejia, L.R. (2000) How Much Does Performance Matter? A MetaAnalysis of CEO Pay Studies. Journal of Management, 26, 301-339. http://dx.doi.org/10.1177/014920630002600207

[3] Lewellen, W.G. and Huntsman, B. (1970) Managerial Pay and Corporate Performance. The American Economic Review, 60, 710-720.

[4] Coughlan, A.T. and Schmidt, R.M. (1985) Executive Compensation, Management Turnover and Firm Performance: An Empirical Investigation. Journal of Accounting and Economics, 7, $43-66$.

[5] Abowd, J.M. (1990) Does Performance Based Managerial Compensation Affect Corporate Performance? Industrial 
and Labor Relations Review, 43, 52-73. http://dx.doi.org/10.1016/0165-4101(85)90026-6

[6] Hall, B.J. and Liebman, J.B. (1998) Are CEOs Really Paid Like Bureaucrats? The Quarterly Journal of Economics, 113, 653-691. http://dx.doi.org/ 10.1162/003355398555702

[7] Sapp, S.G. (2008) The Impact of Corporate Governance on Executive Compensation. European Financial Management, 14, 710-746. http://dx.doi.org/ 10.1111/j.1468-036X.2008.00443.x

[8] Conyon, M.J. and He, L. (2008) Executive Compensation and CEO Equity Incentives in China’s Listed Firms. Working Paper, ESSEC Business School, Wharton School, and SUNY.

[9] Sigler, K.J. (2011) CEO Compensation and Company Performance. Business and Economics Journal, 31, 1-8.

[10] Chow, I.H. (1992) Chinese Workers' Attitudes towards Compensation Practices in the People’s Republic of China. Employee Relations, 14, 41-55. http://dx.doi.org/ 10.1108/01425459210013896

[11] Kato, T. and Long, C. (2006) Executive Compensation, Firm Performance, and Corporate Governance in China: Evidence from Firms Listed in the Shanghai and Shenzhen Stock Exchanges. Economic Development and Cultural Change, 54, 945-983. http://dx.doi.org/10.1086/503583

[12] Agrawal, A. and Walkling, R.A. (1994) Executive careers and compensation surrounding Takeover Bids. Journal of Finance, 49, 985-1014. http://dx.doi.org/10.1111/j.1540-6261.1994.tb00085.x

[13] Bebchuk, L.A., Fried, J.M. and Walker, D.I. (2002) Managerial Power and Rent Extraction in the Design of Executive Compensation. University of Chicago Law Review, 69, 751-846. http://dx.doi.org/10.3386/w9068

[14] Mengistae, T. and Xu, L.C. (2004) Agency Theory and Executive Compensation: The Case of Chinese State Owned Enterprises. Journal of Labor Economics, 22, 615-637. http://dx.doi.org/10.1086/383109

[15] Firth, M., Fung, P.M.Y. and Rui, O.M. (2006) Corporate Performance and CEO Compensation in China. Journal of Corporate Finance, 12, 693-714. http://dx.doi.org/10.1016/j.jcorpfin.2005.03.002

[16] Firth, M., Fung, P.M.Y. and Rui, O.M. (2007) How Ownership and Corporate Governance Influence Chief Executive Pay in China's Listed Firms. Journal of Business Research, 60, 776-785.

[17] Li, D., Moshirian, F., Nguyen, P. and Tan, L.W. (2007) Corporate Governance or Globalization: What Determines CEO Compensation in China? Research in International Business and Finance, 21, 32-49.

[18] Conyon, M.J. and He, L. (2008) Executive Compensation and CEO Equity Incentives in China’s Listed Firms. Working Paper, ILR School, Cornell University, Ithaca.

[19] Eisenhardt, K.M. (1989) Agency Theory: An Assessment and Review. Academy of Management Review, 14, 57-74. http://dx.doi.org/10.5465/AMR.1989.4279003

[20] Weisbach, M.S. (1988) Outside Directors and CEO Turnover. Journal of Financial Economics, 20, 431-460. http://dx.doi.org/10.1016/0304-405X(88)90053-0

[21] Fama, E.F. and Jensen Michael, C. (1983) Separation of Ownership and Control. Journal of Law and Economics, 26, 301-326.

[22] Chen, J.J., Liu, X. and Li, W. (2010) The Effect of Insider Control and Global Benchmarks on Chinese Executive Compensation. Corporate Governance: An International Review, 18, 107-123. http://dx.doi.org/10.1111/j.1467-8683.2010.00788.x

[23] Conyon, M. and He, L. (2011) Executive Compensation and CEO Equity Incentives in China’s Listed Firms. Journal of Corporate Finance, 4, 1158-1175.

[24] Murphy, K.J. (1999) Executive Compensation. In: Ashenfelter, O. and Card, D., Eds., Handbook of Labor Economics, Elsevier Science North, Holland, 2485-2563. 
Scientific Research Publishing (SCIRP) is one of the largest Open Access journal publishers. It is currently publishing more than 200 open access, online, peer-reviewed journals covering a wide range of academic disciplines. SCIRP serves the worldwide academic communities and contributes to the progress and application of science with its publication.

Other selected journals from SCIRP are listed as below. Submit your manuscript to us via either submit@scirp.org or Online Submission Portal.
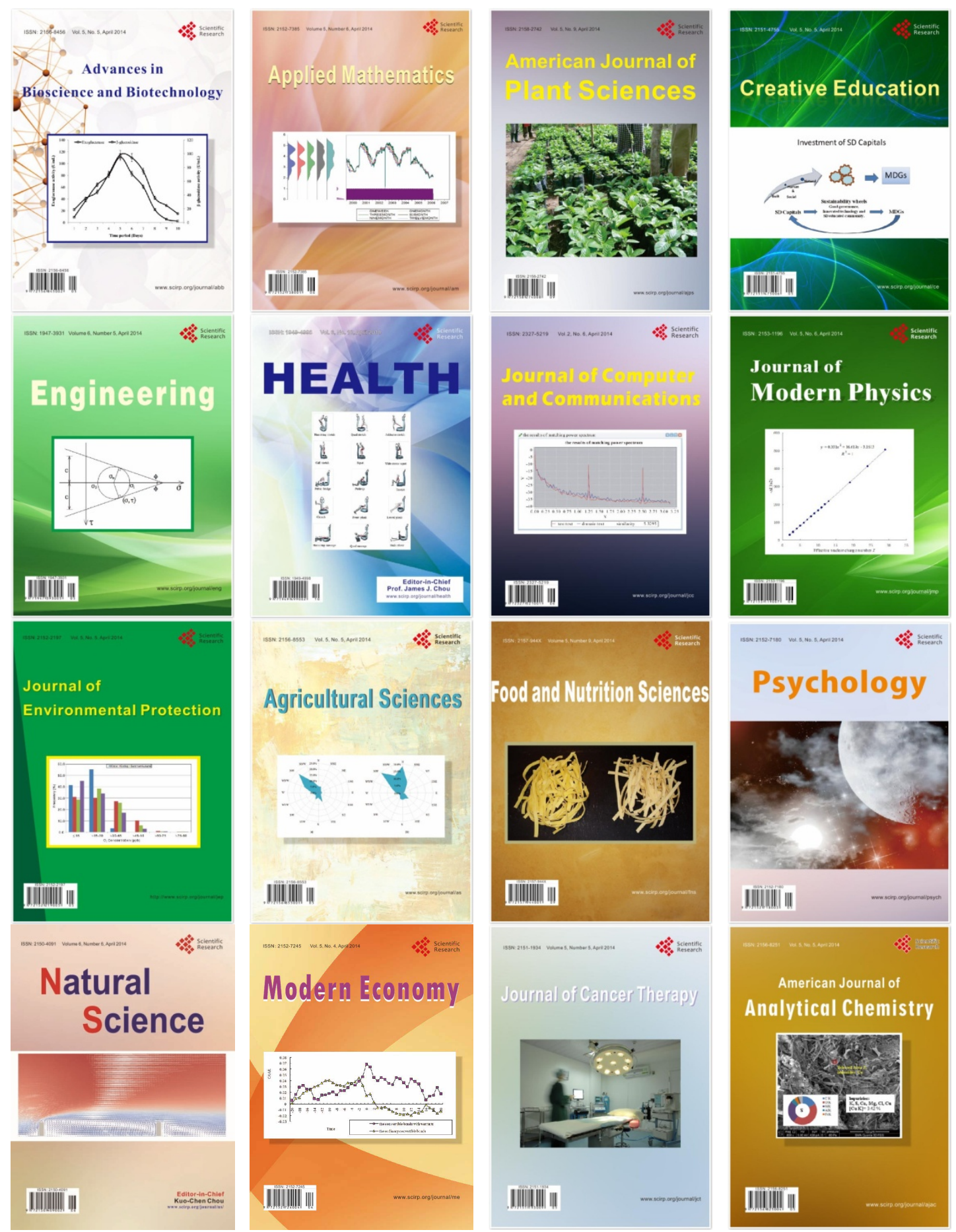